\title{
Chromosome 14 markers in rheumatoid arthritis
}

\author{
W OLliER, ${ }^{1}$ W THOMSON ${ }^{4}$ S WELCH, ${ }^{2}$ G G DE LANGE,${ }^{5}$ AND A SILMAN
}

From the Departments of ${ }^{1}$ Immunology, ${ }^{2}$ Biochemistry, and ${ }^{3}$ Epidemiology, The London Hospital Medical College, London; the ${ }^{4}$ Tissue Typing Laboratory, St Mary's Hospital, Manchester; and the ${ }^{5}$ Central Laboratory of the Netherlands, Red Cross Blood Transfusion Service, Amsterdam, The Netherlands

SUMMARY Phenotype frequencies for variants of the chromosome 14 markers, $\alpha_{1}$ antitrypsin (protease inhibitor-Pi), and immunoglobulin heavy chain gene allotypes (Gm and Am) were examined in affected and unaffected members of multicase rheumatoid arthritis (RA) families and compared with published population data. Significantly higher frequencies of phenotypes containing $\mathrm{Pi}^{*} \mathrm{Z}$ and $\mathrm{Pi}^{*} \mathrm{~S}$ were observed in unrelated index RA cases compared with UK population data. There was also a higher frequency of $\mathrm{Pi}^{*} \mathrm{Z}$ in family members without $\mathrm{RA}$ than in population controls but no such difference for the frequency of $\mathrm{Pi}^{*} \mathrm{~S}$. No difference in the frequency of PiM1M2 heterozygotes was seen between patients with RA and population controls. An examination of clinical data failed to show any relation between any particular feature of RA and positivity for $\mathrm{Pi}^{*} \mathrm{Z}$ or $\mathrm{Pi}^{*} \mathrm{~S}$. No significant differences in frequency of $\mathrm{Gm}$ phenotypes were observed between patients with RA and controls. Significant association was found, however, between $\mathrm{Pi}^{*} \mathrm{Z}$ and $\mathrm{Gm}$ phenotypes containing $\mathrm{Gm}(\mathrm{zax} ; \mathrm{g})$. These associations are interpreted as indicating linkage disequilibria between these alleles. No interactions between DR4 and either $\mathrm{G} 1 \mathrm{~m}(\mathrm{z}),(\mathrm{a})$, or $(\mathrm{x})$ allotypes were apparent in patients with RA. A significant association was seen in the index RA cases between DR4 and Pi phenotypes carrying Z or S alleles. Observations from this study provide evidence for the existence of a genetic component for RA susceptibility encoded on chromosome 14. An interactive effect of these genes with DR4 towards susceptibility appears likely.

Key words: Pi, immunoglobulin allotypes, Gm, HLA.

A genetic basis for RA susceptibility is suggested by the known familial tendency to develop this disease and by a higher concordance rate for RA in monozygotic twins than in dizygotic twins. ${ }^{1}$ The relatively low figure of $32 \%$ concordance for RA development in monozygotic twins gives a clear indication of the role of non-genetic 'environmental' factors contributing to the disease development.

A major component of the genetic susceptibility to RA has been shown to be encoded within the HLA region, ${ }^{2}$ with DR4 being associated with RA in many populations. ${ }^{3}$ Family studies have now demonstrated linkage of RA susceptibility with HLA. ${ }^{4}$

Accepted for publication 29 February 1988.

Correspondence to Dr W Ollier, Department of Immunology, The London Hospital Medical College, Turner Street, London E1 2AD.
Additional associations have been described for RA and $\alpha_{1}$ antitrypsin (Pi) and IgG allotypes ( $\left.\mathrm{Gm}\right)$. It is now known that the genes for $\mathrm{Pi}$ and $\mathrm{Gm}$ are linked ${ }^{5}$ and are located on chromosome $14 .^{6}$ The alleles $\mathrm{PiZ},{ }^{7-10} \mathrm{PiS},{ }^{11}$ and subtypes of $\mathrm{PiM}^{12}{ }^{13}$ have been found to be at raised frequency in patients with RA. An association has also been observed with the $\mathrm{G} 1 \mathrm{~m}(\mathrm{x})$ allotype in DR4 positive patients, suggesting that some form of epistatic interaction between $\mathrm{Gm}$ and HLA exists. ${ }^{14-16}$

Associations between RA and chromosome 14 encoded products still have to be well characterised, however, and some studies have failed to show a clear association between RA and either $\mathrm{Pi}^{17-20}$ or $\mathrm{Gm}$ allotypes. ${ }^{21}$

This study therefore had two aims. Firstly, to examine the associations between $\mathrm{Pi}$ and $\mathrm{Gm}$ with RA and, secondly, to determine the influence of these markers in explaining disease susceptibility in families with RA. 


\section{Patients and methods}

\section{S U B J E CTS}

The subjects for this study were drawn from multicase families with at least two living first degree relatives satisfying American Rheumatism Association (ARA) criteria for classical or definite RA. ${ }^{22}$ An explanation of their collection and clinical examination has been reported elsewhere. ${ }^{4}$ For this analysis family members were classified into the following groups: (a) index cases, i.e., the first reported RA case for each family (used in testing for associations); (b) affected cases; i.e., family members with classical or definite RA: (c) suspicious cases, i.e., family members in whom there was at least one clinical or laboratory feature suggestive of inflammatory arthritis but who did not satisfy the ARA criteria for definite RA; $(d)$ unaffected cases, i.e., family members who were not affected or suspicious cases.

CONTROL FIGURES TAKEN FROM

PUB LISHED DATA

Frequencies for $\mathrm{Pi}$ and $\mathrm{Gm}$ phenotypes in normal Caucasoid controls have been reported elsewhere. $^{13152324}$

\section{LABORATORY TECHNIQUES}

Pi phenotypes were ascertained for serum samples by isoelectric focusing on commercially available polyacrylamide gel plates ( $\mathrm{pH}$ range $4 \cdot 0-5 \cdot 0$; LKB). ${ }^{25}$ On completion, gels were stained with Coomassie blue and destained before reading. $\mathrm{Pi}$ types were read blind by two independent observers, and samples giving unclear results were rerun.
Immunoglobulin allotypes $(\mathrm{Gm}, \mathrm{Am}$, and $\mathrm{Km}$ were identified by haemagglutination inhibitiow assays of serum samples ${ }^{26}$ and included G1m $(\mathrm{z}, \mathrm{a}, \mathrm{x}, \mathrm{f}), \quad \mathrm{G} 2 \mathrm{~m}(\mathrm{n}), \mathrm{G} 3 \mathrm{~m}(\mathrm{~g}, \mathrm{~b} 0, \mathrm{~b} 1, \mathrm{~b} 3, \mathrm{~b} 5, \mathrm{~s}, \mathrm{t}, \mathrm{c} 3, \mathrm{c5}) \mathrm{m}$ $\operatorname{A} 2 m(1,2)$, and the $x$ light chain allotypes $\operatorname{Km}(1,3)$ 울 $\mathrm{G} 3 \mathrm{~m}(\mathrm{~b} 0, \mathrm{~b} 1, \mathrm{~b} 3$, and b5) usually occur together an $\Phi$ are summarised as $\mathrm{G} 2 \mathrm{~m}(\mathrm{~b})$.

HLA typing was performed using procedure described elsewhere. ${ }^{27} 28$

STATISTICAL ANALYSIS

$\chi^{2}$ Analysis was used to compare phenotype fre quencies seen in the unrelated index cases and nop mal controls. Levels of significance were no: corrected for the number of comparisons made.

Similarly, the phenotype frequencies were com $=$ pared for the index cases and other affected an $\bar{P}$ non-affected individuals within the families. $\mathbb{P}^{\infty}$ formal cosegregation analysis was then undertaken

Table 2 Frequency of PiM subtypes in multiple RA cas families

\begin{tabular}{|c|c|c|}
\hline $\begin{array}{l}\text { PiM } \\
\text { subtype }\end{array}$ & $\begin{array}{l}\text { Index } \\
\text { cases } \\
(n=60)\end{array}$ & $\begin{array}{l}\text { UK } \\
\text { controls } \\
(n=223)\end{array}$ \\
\hline M1M1 & $55.0(33) \dagger$ & $73.5(164)$ \\
\hline M1M2 & $11 \cdot 7 \quad(7)$ & $12 \cdot 1$ \\
\hline M1S & $18 \cdot 3$ (11) & (12) \\
\hline M1Z & $8.3 \quad(5)$ & $3 \cdot 6$ \\
\hline M2M2 & $5 \cdot 0 \quad(3)$ & $2 \cdot 7$ \\
\hline M2S & $0 \cdot 0$ & $1 \cdot 3$ \\
\hline M2Z & $1 \cdot 7 \quad$ (1) & 0.0 \\
\hline
\end{tabular}

*See ref 13.

†Values are percentage (No).

Table 1 Frequency of Pi phenotypes in multiple $R A$ case families

\begin{tabular}{|c|c|c|c|c|c|}
\hline Phenotype & $\begin{array}{l}\text { Index } \\
\text { cases } \\
\text { alone } \\
(n=63)\end{array}$ & $\begin{array}{l}\text { UK } \\
\text { controls* } \\
(n=4565)\end{array}$ & $\begin{array}{l}\text { All } \\
\text { affected } \\
\text { casest } \\
(n=118)\end{array}$ & $\begin{array}{l}\text { Suspicious } \\
\text { cases } \ddagger \\
(n=89)\end{array}$ & $\begin{array}{l}\begin{array}{l}\text { Unaffected } \\
\text { cases } \\
(n=278)\end{array} \\
\text { 을 }\end{array}$ \\
\hline $\mathbf{M M}$ & $71 \cdot 4(45) \S$ & $88.5(4042)$ & $72 \cdot 0(85)$ & $76.4(68)$ & $84 \cdot 2(234)$ \\
\hline MS & $15.9(10)^{i}$ & $8.0 \quad(366)$ & 14.4 (17) & $13 \cdot 5(12)$ & $5.4(15)$ \\
\hline MZ & $9.5(6)^{1}$ & $1.5 \quad(71)$ & $10 \cdot 2(12)$ & $9.0 \quad(8)$ & 9.7 (27) \\
\hline MF & 0.0 & $0.6 \quad(30)$ & $0.8 \quad$ (1) & & 0.0 S \\
\hline M? & $1.6 \quad(1)$ & & $1.7 \quad(2)$ & & 0.4 \\
\hline SS & 0.0 & $0.4 \quad$ (16) & 0.0 & $1 \cdot 1 \quad(1)$ & 0.0 \\
\hline SZ & $1.6 \quad$ (1) & $0.2 \quad(10)$ & $0.8 \quad$ (1) & 0.0 & 0.0 \\
\hline $\mathbf{Z Z}$ & 0.0 & $0.04 \quad$ (2) & 0.0 & $0 \cdot 0$ & 0.4 \\
\hline \multicolumn{6}{|c|}{$\begin{array}{l}\text { *See text. } \\
\text { †Including index cases. } \\
\text { †See ref } 22 \text {. } \\
\text { \&Values are percentage }(\mathrm{No}) \\
\text { ISample } v \text { controls } 0.05>\mathrm{p}>0.01 \\
\text { 'Sample } v \text { controls } \mathrm{p}<0.001\end{array}$} \\
\hline
\end{tabular}


of siblings with at least one affected and one nonaffected offspring of parents heterozygous for either the $\mathrm{S}$ or $\mathrm{Z}$ allele. The results were displayed as $2 \times 2$ tables.

\section{Results}

Table 1 summarises the frequencies of $\mathrm{Pi}$ phenotypes in multiple RA case families. When compared

Table 3 Offspring of MS heterozygous parents

\begin{tabular}{lll}
\hline Allele & $\begin{array}{l}\text { Affected } \\
(\text { No })\end{array}$ & $\begin{array}{l}\text { Unaffected } \\
(\text { No) }\end{array}$ \\
\hline $\mathrm{S}$ & 15 & 12 \\
$\mathrm{M}$ & 12 & 20 \\
\hline
\end{tabular}

$\chi^{2}=1.92, p=N S$.

Table 4 Offspring of $M Z$ heterozygous parents

\begin{tabular}{lll}
\hline Allele & $\begin{array}{l}\text { Affected } \\
\text { (No) }\end{array}$ & $\begin{array}{l}\text { Unaffected } \\
\text { (No) }\end{array}$ \\
\hline $\mathrm{Z}$ & 8 & 6 \\
$\mathrm{M}$ & 3 & 6 \\
\hline
\end{tabular}

$\chi^{2}=1 \cdot 24, p=N S$. with a large panel of UK controls significantly higher frequencies of $\mathrm{MZ}$ and $\mathrm{MS}$ phenotypes were observed in the unrelated index cases. These increases were also seen in both the overall panel of affected cases and in the suspicious cases. The group of 'suspicious' individuals was differentiated to eliminate any possible patients with RA from the panel of unaffected family members. The frequency of the MS phenotype in the unaffected members $(5 \cdot 4 \%)$ was similar to that in the controls $(8.0 \%)$. In contrast, the frequency of $\mathrm{MZ}$ phenotypes remained raised $(9.7 \% \vee 1.5 \%)$.

The M1M2 subtypes were available for 60 of the index cases (Table 2). No significant difference in the frequency of M1M2 heterozygotes could be seen between patients with RA and published controls. The reduction in M1 homozygotes in our patients with RA appears to be consistent with the increased frequency of $S$ and $Z$ bearing phenotypes. The $\mathrm{Pi}$ status was then compared in the unaffected offspring and those with RA of MS and MZ heterozygous parents in families with at least one offspring of each type. The results showed a slight but non-significant distortion towards affected offspring, who were more likely to inherit the $\mathrm{S}$ and $\mathrm{Z}$ allele respectively (Tables 3 and 4).

Table 5 summarises the frequencies of $\mathrm{Gm}$ phenotypes observed. When compared with published controls no significant difference for any

Table $5 \mathrm{Gm}$ phenotypes in multiple RA case families

\begin{tabular}{|c|c|c|c|c|c|}
\hline$G 1 m ; G 2 m ; G 3 m$ & $\begin{array}{l}\text { Index } \\
\text { cases } \\
(n=62)\end{array}$ & $\begin{array}{l}\text { Controls }{ }^{*} \\
(n=792)\end{array}$ & $\begin{array}{l}\text { Affected } \\
\text { casest } \\
(n=120)\end{array}$ & $\begin{array}{l}\text { Suspicious } \\
\text { cases } \\
(n=89)\end{array}$ & $\begin{array}{l}\text { Unaffected } \\
\text { cases } \\
(n=271)\end{array}$ \\
\hline f;n;b & $40 \cdot 3(25) 8$ & $43.4(344)$ & $41.8(49)$ & $32.6(29)$ & $37 \cdot 3(101)$ \\
\hline$f ; n ; b c^{3} c^{5}$ & 1.6 (1) & $0.5 \quad$ (4) & $0.8 \quad$ (1) & 0.0 & $0.4 \quad$ (1) \\
\hline f; $\cdots ; b$ & 1.6 & $6 \cdot 3 \quad(59)$ & $2.5 \quad(3)$ & $11 \cdot 2(10)$ & $5 \cdot 5 \quad$ (15) \\
\hline $\operatorname{zax} ; \cdot \cdot ; g$ & $4.8 \quad$ (3) & $4 \cdot 3 \quad$ (34) & $5.0 \quad(6)$ & $7.8 \quad(7)$ & $6 \cdot 3 \quad(17)$ \\
\hline zaxf;n;g & 0.0 & $0 \cdot 0$ & 0.0 & $1 \cdot 1 \quad$ (1) & $0.4 \quad$ (1) \\
\hline zaxf;n;gb & $6 \cdot 5 \quad(4)$ & $9 \cdot 1 \quad(72)$ & $\begin{array}{ll}7 \cdot 5 & \text { (9) }\end{array}$ & $7.8 \quad(7)$ & $5.2 \quad(14)$ \\
\hline zaxf;•;gb & $4.8 \quad(3)$ & $5.7 \quad(45)$ & $7.5 \quad$ (9) & $4.4 \quad$ (4) & $6.6 \quad(18)$ \\
\hline$z a x ; \cdots ; g b$ & $3 \cdot 2 \quad(2)$ & $0.1 \quad$ (1) & $1.7 \quad(2)$ & 0.0 & 0.0 \\
\hline za;•;g & $3 \cdot 2 \quad(2)$ & $4.5 \quad$ (36) & $5.0 \quad(6)$ & $1 \cdot 1 \quad$ (1) & $4 \cdot 1$ \\
\hline zaf;:-;gb & 14.5 (9) & $8.3 \quad(66)$ & 11.7 (14) & $10 \cdot 1$ & $10.0 \quad(27)$ \\
\hline zaf;n;gb & $16 \cdot 1(10)$ & 15.9 (126) & $14 \cdot 2$ (17) & $23.6(21)$ & $21.0 \quad$ (57) \\
\hline zaf;··;b & 0.0 & 0.0 & 0.0 & $1 \cdot 1$ (1) & 0.4 \\
\hline zaf;:·;bst & 0.0 & 1 & 0.0 & 0.0 & 0.7 \\
\hline$z a ; \cdot \cdot ; g b$ & 0.0 & $0 \cdot 1$ & $0 \cdot 0$ & $1 \cdot 1 \quad$ (1) & 0.7 \\
\hline$z a ; \cdots ; g b^{0} b^{3} b^{5} s t$ & 0.0 & & $0.8 \quad$ (1) & 0.0 & 0.4 \\
\hline$z a ; n ; g$ & $1.6 \quad(1)$ & 0.0 & $0.8 \quad$ (1) & 0.0 & 0.4 \\
\hline za;n;gb & 0.0 & 0.0 & $0.8 \quad(1)$ & 0.0 & $0 \cdot 0$ \\
\hline zaf;n;bst & 1.6 & $0 \cdot 0$ & $0.8 \quad$ (1) & 0.0 & 0.0 \\
\hline zaf;n;b & 0.0 & $0.5 \quad$ (4) & 0.0 & 0.0 & 0.7 \\
\hline
\end{tabular}

*See ref 29.

tIncluding index cases.

$\ddagger$ See text.

$\$$ Values are percentages (Nos).

Rare phenotypes discussed in ref 29. 
particular $\mathrm{Gm}$ phenotype in patients with RA was seen. The $\mathrm{Gm}$ frequencies in all patients with RA and published controls were remarkably similar.

The immunoglobulin $x$ light chain allotype $\mathrm{Km}(1)$ was present in index cases and affected family members at frequencies of $11.4 \%$ and $11.3 \%$ respectively. A frequency of $17.9 \%$ for $\mathrm{Km}(1)$ has been reported for unaffected controls. ${ }^{24}$ No significant differences were seen between patients with RA and controls for the frequencies of the $\operatorname{IgA}$ allotypic markers $\operatorname{Am}(1)$ or $\operatorname{Am}(2)$.

An interesting observation is that, of the $46 \mathrm{PiZ}$ individuals, 39 had $\mathrm{Gm}$ phenotypes containing the $\mathrm{G} 1 \mathrm{~m}(\mathrm{z})$ and $(\mathrm{a})$ allotypes $\left(\chi^{2}=16.6, \mathrm{p}<0.001\right)$ and 19 the $\mathrm{Gm}(\mathrm{zax} ; \mathrm{g})$ haplotype $\left(\chi^{2}=15 \cdot 0, \mathrm{p}<0 \cdot 001\right)$. Such associations may reflect linkage disequilibria between these alleles.

An analysis of the relation between DR4 status and $\mathrm{Gm}$ allotypes in patients with RA failed to show any increase in the proportion of $\mathrm{G} 1 \mathrm{~m}(\mathrm{z})$ or $\mathrm{G} 1 \mathrm{~m}(\mathrm{x})$ allotypes in DR4 positive patients compared with those who were DR4 negative (Table 6). Such an analysis for Pi markers, however, showed a higher proportion of $\mathrm{PiZ}$ and $\mathrm{PiS}$ containing phenotypes in DR4 positive patients than in those who were DR4 negative (Table 7).

Table 6 Relations between HLA-DR4 status and Gm markers in $R A$

\begin{tabular}{lll}
\hline Gm marker & \multicolumn{2}{l}{ Index cases $(n=60)$} \\
\cline { 2 - 3 } & $\begin{array}{l}\text { DR4 } \\
\text { positive } \\
(N o)\end{array}$ & $\begin{array}{l}\text { DR4 } \\
\text { negative } \\
(\text { No })\end{array}$ \\
\hline G1m(z) positive & 21 & 13 \\
G1m(z) negative & 19 & 7 \\
G1m(x) positive & 7 & 5 \\
G1m(x) negative & 33 & 15
\end{tabular}

No significant associations.

Table 7 Relations between HLA-DR4 status and Pi markers in $R A$

\begin{tabular}{lll}
\hline Pi marker & \multicolumn{2}{l}{ Index cases $(n=61)$} \\
\cline { 2 - 3 } & $\begin{array}{ll}\text { DR4 } \\
\text { positive } \\
(N o)\end{array}$ & $\begin{array}{l}\text { DR4 } \\
\text { negative } \\
(\text { No })\end{array}$ \\
\hline PiS or PiZ positive & 16 & 3 \\
PiS or PiZ negative & 24 & 18 \\
\hline
\end{tabular}

$\chi^{2}=4 \cdot 2, p<0.05$.

\section{Discussion}

In keeping with some other studies we have observed an increase in the frequency of $\mathrm{Pi}^{*} \mathrm{Z}$ is patients with RA and, additionally, have shown a increase in the frequency of $\mathrm{Pi}^{*} \mathrm{~S}$. Other worker have, however, shown no such association. Interesf ingly, the current study found higher frequencies $\&$ PiZ $(11.1 \%)$ and PiS (17.5\%) than a similar bitf larger series recently published, which found $1.4 \%$ and $9.7 \%$ respectively, neither of which was significantly increased compared with controls. ${ }^{20}$ It is diff $\dot{\bar{E}}$ cult to explain the disparity in these results, but one possible factor is that the index cases in the curren study were drawn from multicase families and from sporadic cases in the latter. Thus Pi would appear to 'contribute' towards RA susceptibility. It is know? that these particular Pi variants, present at low fres quency in the normal population, are associateg quantitatively with different levels of serum $\alpha_{1}$ ant? trypsin. When the concentration of $\alpha_{1}$ antitrypsin $\vec{s}$ expressed as a percentage of that found in the PiMM genotype (i.e., $100 \%$ ) reduced levels are found fof MS $(88-80 \%), \quad M Z(67-59 \%)$, SS $(58 \%)$, S\& (37-36\%), and $\mathrm{ZZ}(7-16 \%){ }^{23}$ No quantitative differences have been reported for M1 and M2 types. There is variation between individuals witb the same $\mathrm{Pi}$ type, however, and some overlapo of levels may exist, dependent on the individua s examined.

A reduction in the $\alpha_{1}$ antitrypsin level should hav the effect of increasing the action of proteolytic enzymes. $\alpha_{1}$ Antitrypsin is a major inhibitor of elastase, and it has been suggested that any reduc tion in its level could lead to increased destruction of joint cartilage by leucocyte elastase released by infil: trating cells during inflammatory rheumatoiu processes. $^{8}$

Associations between $\mathrm{Pi}^{*} \mathrm{Z}$ and a variety of puE monary disorders have been described, ${ }^{30} 31$ includ ing patients with RA and fibrosing alveolitis ${ }^{19}$ and individuals with emphysema. ${ }^{32}$ These observations together with the suggestions of increased proteolstic enzyme activity, predict an increase of pulmor ary problems or disease severity, or both, in fami RA cases with the PiZ variant. Unfortunately the sample size in this study may be too small to address this problem satisfactorily.

The increase of the MS phenotype frequency patients with RA and its subsequent reduction of unaffected individuals underlines its possible contrit bution to RA susceptibility. We were unable to show, however, that the observed distortion in the cosegregation of either $\mathrm{S}$ or $\mathrm{Z}$ with $\mathrm{RA}$ in these families is significant. The high frequency of $\mathrm{Pi}^{*} \mathrm{Z}$ 角 all groups of family members, including unaffecte 
members, is unexpected. There have been several reports of a positive transmission bias of $\mathrm{PiZ}$ alleles from men, ${ }^{33}$ and this may go some way towards explaining this observation. Thus $\mathrm{PiZ}$ bearing haplotypes could represent a susceptibility factor contributing towards RA development for certain individuals and through this mechanism of 'loading the dice' may be carried in their family members more frequently than expected by chance.

No particular $\mathrm{Gm}$ allotype was raised in frequency for any set of individuals in these families with RA. Associations were seen, however, between certain $\mathrm{Pi}$ variants and $\mathrm{Gm}$ allotypes and haplotypes. The obvious explanation for this finding is that linkage disequilibrium exist between these alleles. Although it has been shown that $\mathrm{Pi}$ and $\mathrm{Gm}$ are linked, ${ }^{6}$ the recombination fraction between them is estimated to be $0.26,{ }^{5}$ and it would be unusual for linkage disequilibria to be maintained over this distance. An analogy has been drawn between the observed transmission bias of $\mathrm{PiZ}$ containing haplotypes and the effects of the $\mathrm{T}$ locus in the mouse, ${ }^{5}$ which can disturb both segregation ratios and recombination distances between genes. ${ }^{34}$ Thus it is not impossible to find certain alleles some distance apart which maintain the phenomenon of linkage disequilibrium.

Previous studies have shown an increase of the G1m(x) allotype in DR4 positive RA patients, implying some level of interaction with the HLA system. ${ }^{4} 15$ This relation could not be observed in our data. A similar situation can be seen, however, whereby significantly more $\mathrm{PiS}$ and $\mathrm{PiZ}$ containing phenotypes are present in DR4 positive patients than in DR4 negative ones. As linkage disequilibrium appears to exist between $\mathrm{Gm}(\mathrm{zax} ; \mathrm{g})$ and $\mathrm{PiZ}$, a reconciliation between these observations may be that certain chromosome $14 \mathrm{Pi}-\mathrm{Gm}$ haplotypes can interact with certain chromosome 6 HLA haplotypes to confer greater RA susceptibility on individuals.

Several hypotheses may explain the contribution of chromosome 14 encoded products to RA susceptibility. One is that $\mathrm{Pi}$ may have a direct role in RA pathogenesis and that Gm allotypes, such as G1m(x), may be 'innocent bystanders' carried along through linkage disequilibria. Alternatively, it can be argued that $\mathrm{Gm}$ allotypes directly affect the generation of rheumatoid factors.

Another explanation could be that an RA susceptibility gene(s) is in linkage disequilibrium with certain Pi and Gm alleles and could be found more commonly in certain haplotypes. This would not necessarily mutually exclude an additional involvement of Pi and Gm in RA. T cell receptor genes are now known to be encoded also on chromosome
$14 .^{29} 35$ It would therefore not be unreasonable to consider this region of chromosome 14 as being a contender for encoding a component of RA susceptibility.

Certain chromosome 14 encoded products may be involved in immunological recognitive processes and after the action of particular pathogenic challenges lead to a potential autoimmune situation whereby the HLA system is implicated in the intensity of the ensuing reaction. Future studies using DNA probes to examine chromosome 14 associations with RA will be of interest.

WT is supported by the Arthritis and Rheumatism Council of Great Britain. We are grateful to $A M$ van Leeuwen and $\mathrm{PH}$ van Eede for their excellent technical assistance and to Denny Williams for the preparation of this manuscript.

\section{References}

1 Lawrence J S. Rheumatoid arthritis: nature or nurture. Ann Rheum Dis 1970; 29: 357-79.

2 Stastny P. Mixed lymphocyte culture typing cells from patients with rheumatoid arthritis. Tissue Antigens 1974; 4: 571-9.

3 Ollier W, Festenstein $H$. Rheumatoid arthritis and genetic susceptibility. Perspectives in Rheumatology (in press).

4 Ollier W, Silman A, Gosnell N, et al. HLA and rheumatoid arthritis: an analysis of multicase families. Disease Markers 1986; 4: 85-98.

5 Gedde-Dahl T, Frants R R, Olaisen B, Eriksson A W, van Loghem E, Lamm L. The Gm-Pi linkage heterogeneity in view of PiM subtypes. Ann Hum Genet 1981; 45: 143-53.

6 Cox D W, Markovic V D, Teshima I E. Genes for immunoglobulin heavy chains and for alpha-1-antitrypsin are localised to specific regions of chromosome 14q. Nature 1982; 297: 428-30.

7 Cox D W, Huber O. Rheumatoid arthritis and alpha-1antitrypsin. Lancet 1976; i: 1216-7.

$8 \mathrm{Cox} \mathrm{D}$ W, Huber O. Association of severe rheumatoid arthritis with heterogeneity for alpha-1-antitrypsin deficiency. Clin Genet 1980; 17: 153-60.

9 Beckman G, Beckman L, Bjelle A, Dahlquist S R. Alpha-1antitrypsin types and rheumatoid arthritis. Clin Genet 1984; 25: 492-9.

10 Buisseret P D, Pembrey M E, Lessof M H. Alpha-1-antitrypsin phenotypes in rheumatoid arthritis and ankylosing spondylitis. Lancet 1977; ii: 1358-9.

11 Collins R L, Turner R A, Johnson A M, Whitley N $\bar{O}, \bar{M} c \bar{L}$ ean $\mathbf{R} \mathbf{L}$. Obstructive pulmonary disease in rheumatoid arthritis. Arthritis Rheum 1976; 19: 623-8.

12 Mitchell R J, Fabb S A. Serum proteins, alpha-1-antitrypsin (Pi) and Gc (VDBP) and rheumatoid arthritis. Disease Markers 1984; 2: 461-8.

13 Thomson W, Dyer P A, Sanders P A, Grennan D M. C3, Gm and $\mathrm{Pi}$ polymorphisms in rheumatoid arthritis. Disease Markers 1986; 4: 145-50.

14 Propert D N, Kay P, McKluskey J, Zilko P J, Mathews J. Immunoglobulin allotypes in rheumatoid arthritis. In: Dawkins $\mathrm{R}$ L, Christiansen F T, Zilko P J, eds. Immunogenetics in rheumatology. Musculoskeletal disease and D-penicillamine. Amsterdam: Excerpta Medica, 1982: 127-9.

15 Sanders P A, de Lange G G, Dyer P A, Grennan D M. Gm and $\mathrm{Km}$ allotypes in rheumatoid arthritis. Ann Rheum Dis 1985; 44: 529-32.

16 Puttick A, Briggs D, Welsh K, Jacoby R, Williamson E, Jones $\mathrm{V}$. Extended haplotypes in rheumatoid arthritis and preliminary 
evidence for an interaction with immunoglobulin genes. Disease Markers 1986; 4: 139-44.

17 Brackertz D, Kueppers F. Alpha-1-antitrypsin phenotypes in rheumatoid arthritis. Lancet 1977; ii: 934-5.

18 Sjoblom K, Clot J, Serre H. Alpha-1-antitrypsin phenotypes in rheumatoid arthritis. Lancet 1977; ii: 41-2.

19 Geddes D M, Webley M, Brewerton D A, et al. Alpha-1antitrypsin phenotypes in fibrosing alveolitis and rheumatoid arthritis. Lancet 1977; ii: 1049-51.

20 Sanders P A, Thomson W, Browne D A, Dyer P A, Grennan D M. $\alpha_{1}$ Antitrypsin (PI) allotypes in rheumatoid arthritis. Ann Rheum Dis 1986; 45: 450-3.

21 Gran J T, Gaarder P I, Husby G. IgG heavy chain (Gm) allotypes in rheumatoid arthritis and in healthy individuals seropositive for IgM-rheumatoid factor. Scand J Rheumatol 1985; 14: 144-8.

22 Ropes M W, Bennett G A, Cobb S, Jacox R, Jessar R A. Revision of diagnostic criteria in rheumatoid arthritis. Bull Rheum Dis 1958; 9: 175-6.

23 Cook P J L. The genetics of alpha-1-antitrypsin: a family study in England and Scotland. Ann Hum Genet 1975; 38: 275-87.

24 Fraser G R, Volkers W S, Bernini L F, van Loghem E, Meera-Khan $P$, Nýenhuis $L$ E. Gene frequencies in a Dutch population. Hum Hered 1974; 24: 435-48.

25 Welsh S G, McGregor I A, Williams K. Alpha-1-antitrypsin (Pi) phenotypes in a village population from The Gambia, West Africa. Hum Genet 1980; 53: 233-5.

26 Schanfield M S, van Loghem E. Human immunoglobulin allotypes. In: Weir D M, ed. Handbook of experimental immunology. Vol 3. Oxford. Blackwell, 1986: 94-1-18.
27 Festenstein H, Adams E, Burke J, Oliver R T D, Sachs J Wolf $\mathrm{E}$. The distribution of HLA-A antigens in expatriates. from East Bengal living in London. In: Dausset J, Colombani $\mathrm{J}$. eds. Histocompatibility testing 1972. Copenhagen: Munksgaar毒 1972: 175-8.

28 van Rood J J, van Leeuwen A, Ploem J S. Simultaneoß detection of two cell populations by two colour fluorescence ar application of the recognition of B-cell determinants. Natuve 1976; 262: 795-7.

29 Collins M K L, Goodfellow P N, Spurr N K, et al. The humal T-cell receptor alpha-chain gene maps to chromosome 18 क् Nature 1985; 314: 273-4.

30 Fagerhol M K, Cox W D. Pi polymorphism: genetic, bi $\vec{\circ}$ chemical and clinical aspects of alpha-1-antitrypsin. In: Harris $\mathrm{H}$, Hirschorn K, eds. Advance in human genetics. New Yor fed Plenum Press, 1981: 1-62.

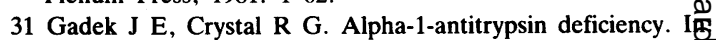
Stanbury J B, ed. Metabolic basis of inherited disease. Net从 York: McGraw-Hill, 1983: 1450-68.

32 Eriksson S. Pulmonary emphysema and alpha-1-antitryps $\overrightarrow{\mathbb{B}}$ deficiency. Acta Med Scand 1964; 175: 197-205.

33 Frants R R, Eriksson A W. PiM subtypes of alpha-1-trypsin 새요 isolate studies. In: Eriksson A W, Forsius H R, Nevanlinng H R, Workman P C, Norio R K, eds. Population structure and genetic disorders. London: Academic Press, 1980: 199-210.-

34 Bennet D. The T locus of the mouse. Cell 1975; 6: 441-5\$

35 Croce $\mathrm{C}$, Isobe $\mathrm{M}$, Palumbo $\mathrm{A}$, et al. Gene for alpha-chain of human T-cell receptor: location on chromosome 14 regiof involved in T-cell neoplasms. Science 1985; 227: 1044-7. 